\title{
Inhibition of Apoptosis and Anti-inflammatory Effects of Embelin
}

\author{
Hee-Jung Yong ${ }^{1,2}$, Gyu Ri Kim ${ }^{2}$, Jin-Jung $\mathrm{Ahn}^{3}$, In-Sook An ${ }^{4}$, Yong-Sam Kim ${ }^{5 *}$ \\ ${ }^{1}$ Department of Lecture, Beauty People Beauty School, Seongnam-si, Gyeonggi-do, Korea \\ ${ }^{2}$ Department of Bioengineering, Konkuk University, Seoul, Korea \\ ${ }^{3}$ Department of Beauty Arts, Suwon Women's University, Suwon-si, Gyeonggi-do, Korea \\ ${ }^{4}$ GeneCellPharm Corporation, Seoul, Korea \\ ${ }^{5}$ Department of Image Industry, Graduate School of Engineering, Konkuk University, Seoul, Korea
}

"Corresponding author: Yong-Sam Kim, Department of Image Industry, Graduate School of Engineering, Konkuk University, 120 Neungdong-ro, Gwangjin-gu, Seoul 05029, Korea Tel.: +82 24503595

Email: gracehelen@konkuk.ac.kr

Received September 1, 2017

Revised November 2, 2017

Accepted November 20, 2017

Published March 30, 2018

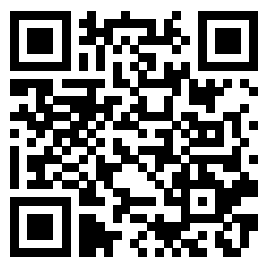

\section{Introduction}

\author{
세포가 감당하기에 지나치게 많은 활성산소가 생성될 경 \\ 우 염증을 일으키게 된다(Wajant et al., 2003). 염증 반응 \\ 에 관여하는 대표적인 전사인자인(Gomez-Nicola et al., \\ 2010; Mazière et al., 1999; Nomoto et al., 2001) nuclear
}

\begin{abstract}
Purpose: Embelin is a major active ingredient of Embelia ribes Burm, belonging to Myrsinaceae, and an important traditional medicinal plant of Indian origin. Embelin has been studied for anti-cancer, anti-inflammatory, and anti-oxidative effects. However, there have been no studies on the use of cosmetic raw materials for embelin. Therefore, in this study, we investigated the inhibition of apoptosis and the anti-inflammatory effect to confirm the possibility of embelin as a cosmetic material. Methods: Cell viability was measured by using water-soluble tetrazolium salt (WST1) assay. Quantitative real time polymerase chain reaction (qRT-PCR) was performed to quantitatively analyze the gene expression patterns of embelin-induced inhibition of apoptosis and anti-inflammatory effects in human dermal fibroblasts (HDFs). Apoptosis enzyme linked immunosorbent assay (ELISA) kit was used to confirm the degree of apoptosis. 5,5', 6,6'-tetrachloro-1,1', 3,3'-tetraethylbenzimidazolylcarbo cyanine iodide (JC-1) mitochondrial membrane potential detection kit was used to measure mitochondrial membrane potential. Results: The WST-1 assay confirmed that the reduced cell viability by hydrogen peroxide $\left(\mathrm{H}_{2} \mathrm{O}_{2}\right)$ was restored by embelin in a concentration-dependent manner. $\mathrm{H}_{2} \mathrm{O}_{2}$-induced apoptosis was restored by embelin, $\mathrm{Bcl}-2$-associated $\mathrm{X}$ protein $(B A X)$ gene expression was decreased and mitochondrial membrane potential difference was increased in a concentration dependent manner. It was confirmed that embelin inhibits apoptosis in $\mathrm{HDFs}$ treated with $\mathrm{H}_{2} \mathrm{O}_{2}$. In order to investigate the anti-inflammatory effect of embelin in $\mathrm{H}_{2} \mathrm{O}_{2}$-treated human dermal fibroblasts, gene expression of cyclooxygenase 2 (COX2), tumor necrosis factor $\alpha$ $(T N F \alpha)$, and interleukin 6 (IL6), which induce inflammation, was examined and found to be decreased by embelin in a concentration dependent manner. Conclusion: These results suggest that embelin has a potential as an anti-aging cosmetic ingredient with inhibition of apoptosis and anti-inflammatory properties.
\end{abstract}

Keywords: Embelin, Anti-oxidative, Anti-inflammatory, Anti-aging, Human dermal fibroblasts 
증 반응을 유도하는 유전자의 발현을 촉진시킨다(Baeuerle, 1988; Longley et al., 1988).

또한 과도하게 생성된 reactive oxygen species (ROS) 는 염증뿐만 아니라 세포사멸을 유발한다. 세포사멸 촉진 유 전자인 $B A X$ 는 평상 시 미토콘드리아 외막에 dimer 형태 로 결합하여 있지만 ROS와 같은 자극에 의해 활성화가 되 면 미토콘드리아로부터 세포질로 cytochrome $\mathrm{C}$ 가 방출되어 caspase 9 와 caspase 3 가 연쇄적으로 활성화된다. 활성화 된 caspase 3 에 의해 유전자 복구 효소인 poly ADP-Ribose polymerase (PARP)의 분리가 일어나 세포의 apoptosis가 유발된다(Kang et al.,2012; Lee et al., 2017; Lee et al., 2016).

Embelin은 인도의 중요한 전통 약용 식물인 Embelia ribes Burm. (Myrsinaceae)의 주요 활성 성분이다. 벤조퀴 논 유도체의 구조를 가진 embelin은 항산화제, 항암제, 항 염증제, 진통제, 구충제, 항균제 등 광범위한 생물학적 활 성을 가지고 있다(Radhakrishana \& Gnanamani, 2014). 그 동안 embelin의 연구동향을 보면 췌장암, 유방암 등 다 양한 암에 대한 항암 효과 연구(Li et al., 2013; Mori et al., 2007)가 주를 이루고, 관절염에 대한 항염 효과 연구 (Dharmapatni et al., 2015)와 간손상, 당뇨병에 대한 항산 화 연구(Naik et al., 2013; Singh et al., 2009)가 있으며, 뇌세포 신경보호효과(Dhadde et al., 2016)에 대한 기타 연 구가 보고되었다.

전 세계적으로 항노화에 대한 화장품 소재 개발 연구가 증 가하고 있으며 embelin에 대한 의약학 분야에서의 항암, 항 염 및 항산화 선행연구가 보고되었으나 embelin의 화장품 원 료 활용으로서의 연구는 전무한 편이다. 따라서 본 연구를 통해 $\mathrm{H}_{2} \mathrm{O}_{2}$ 로 유도된 인간 진피섬유아세포(human dermal fibroblast, $\mathrm{HDF}$ )에서의 embelin의 세포사멸 억제, 항염 효 능을 규명함으로써 embelin의 항노화 화장품 원료로서의 활 용 가능성을 검증하고자 한다.

\section{Methods}

\section{1. 세포 배양}

본 연구에서는 인간 진피섬유아세포(American Type Culture Collection, ATCC, USA)를 사용하였다. 세포배양은 Dulbecco's Modified Eagle Medium (DMEM; HyClone ${ }^{\mathrm{TM}}$, GE Healthcare Life Sciences, USA)에 10\% fetal bovine serum (FBS; HyClone ${ }^{\mathrm{TM}}$ ), 1\% antibiotics (penicillin 100 $\mathrm{IU} / \mathrm{mL}$, streptomycin $100 \mu \mathrm{g} / \mathrm{mL}$; Invitrogen ${ }^{\mathrm{TM}}$, Thermo Fisher Scientific, USA)을 함유한 배지를 사용하였고, $37^{\circ} \mathrm{C}$,
$5 \% \mathrm{CO}_{2}$ 가 유지되는 조건에서 배양하였다.

\section{2. 시료 처리}

Embelin (Sigma-Aldrich, USA)은 순수정제 $(>98 \%)$ 된 분말형태로 구매하여 실험에 사용할 때는 적정 농도로 dimethyl sulfoxide (DMSO; Sigma-Aldrich)에 용해시켜 사용하였다. 세포배양접시에 인간 진피섬유아세포를 $24 \mathrm{~h}$ 배 양한 다음 embelin을 적정 농도로 배지에 첨가하여 $24 \mathrm{~h}$ 동 안 전처리한 후, $\mathrm{H}_{2} \mathrm{O}_{2}$ 를 일정한 농도로 처리하고 $3 \mathrm{~h}$ 후 분석 에 사용하였다.

\section{Cell viability 측정}

세포생존율(cell viability)은 WST-1 assay의 원리를 이 용하여 측정하였다. 이는 세포 내의 미토콘드리아 탈수소효 소(dehydrogenase)와 수용성의 tetrazolium salt가 반응하 여 형성되는 발색물질인 formazan을 이용하여 세포생존율 을 측정하는 방법이다. 96-well plate에 인간 진피섬유아세 포 $\left(3 \times 10^{3}\right.$ cells/well $)$ 를 $100 \mu \mathrm{L}$ 씩 접종하여 $24 \mathrm{~h}$ 배양한 다 음 embelin을 각각 $2.5,5,7.5,10 \mu \mathrm{M}$ 농도로 처리하고, 24 $\mathrm{h}$ 동안 추가 배양하였다. 세포배양 접시에 EZ-Cytox cell viability assay kit reagent (ItsBio, Korea) $10 \mu \mathrm{L}$ 를 첨가 하여 $1 \mathrm{~h}$ 동안 배양한 다음 microplate reader (Bio-Rad Laboratories, USA)를 사용하여 $490 \mathrm{~nm}$ 에서 흡광도를 측정 하였으며, 이를 3 회 반복적으로 수행하여 세포생존율 평균값 과 표준편차를 도출하였다.

\section{RNA 추출과 $\mathrm{cDNA}$ 제조}

Trizol reagent (Invitrogen ${ }^{\mathrm{TM}}$, USA)를 사용하여 세 포배양이 끝난 세포를 용해한 다음 $0.2 \mathrm{~mL}$ chloroform (Biopure, Canada)을 첨가하여 상온에서 반응시킨다. 12000 $\mathrm{rpm}, 4^{\circ} \mathrm{C}$ 조건으로 $20 \mathrm{~min}$ 원심분리를 하여 $\mathrm{mRNA}$ 가 포 함된 상등액과 단백질이 포함된 하등액의 층분리를 확인 한다. 상등액은 $0.5 \mathrm{~mL}$ isopropanol (Biopure)을 첨가하 여 $10 \mathrm{~min}$ 상온에 방치 후 $12000 \mathrm{rpm}, 4^{\circ} \mathrm{C}$ 조건으로 원심 분리를 하여 $\mathrm{RNA}$ 를 침전시키고, $75 \%$ ethanol (Biopure) 을 이용하여 세척한 다음 ethanol을 제거하고 상온에서 건 조시켰다. Diethylpyrocarbonate (DEPC, Biopure) water 로 건조된 $\mathrm{mRNA}$ 를 녹여 실험에 사용하였고, 추출된 $\mathrm{RNA}$ 는 MaestroNano ${ }^{\circledR}$ microspectrophotometer (Maestrogen, USA)을 이용하여 $260 / 280 \mathrm{~nm}$ 의 ratio 1.8 이상인 순도의 $\mathrm{RNA}$ 만을 실험에 사용하였다.

cDNA는 PCR tube에 $1 \mu \mathrm{g}$ RNA, $0.5 \mathrm{ng}$ oligo dT18, $\mathrm{DEPC}$ water를 total $10 \mu \mathrm{L}$ 로 제조한 다음 $70^{\circ} \mathrm{C}$ 에서 10 $\min$ 간 처리하여 RNA 변성을 유도한 후 M-MLV reverse 


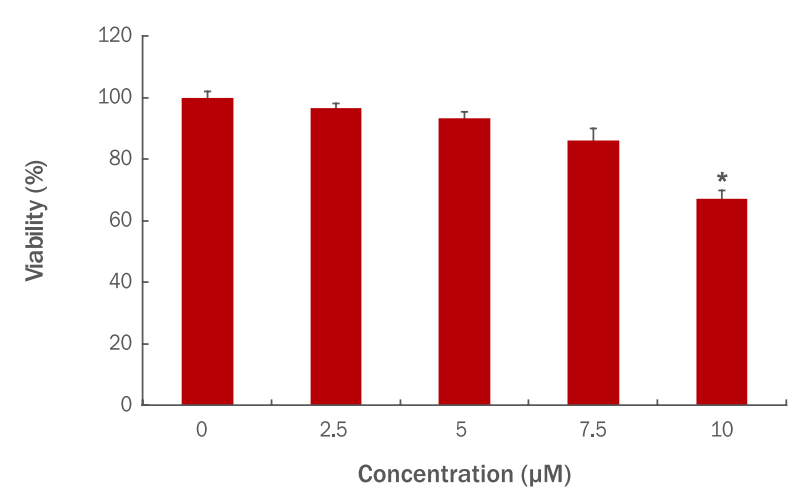

Figure 1. Cell cytotoxicity of embelin on HDFs.

HDFs were seeded on 96-well plate and incubated for $24 \mathrm{~h}$. Then after, the cells were preprocessed with diverse concentrations of embelin. After further incubation for $24 \mathrm{~h}$, the cellular toxicity was measured by WST-1. The graph represents the mean \pm standard deviation of the relative cell viability in each sample from triplicate experiments $\left({ }^{*} p<0.05\right)$. HDFs, human dermal fibroblasts; WST-1, water-soluble tetrazolium salt.

transcriptase (Enzynomics, Korea)를 이용하여 $37^{\circ} \mathrm{C}$ 에서 $1 \mathrm{~h}$ 동안 반응시켜 $\mathrm{cDNA}$ 를 합성하였다.

\section{5. qRT-PCR}

Embelin에 의한 인간 진피섬유아세포 내에서 일어나는 유 전자 발현패턴을 정량적으로 분석하기 위하여 $\mathrm{qRT}-\mathrm{PCR}$ 을 실행하였다. $\mathrm{qRT}-\mathrm{PCR}$ 은 PCR tube에 $0.2 \mu \mathrm{M}$ primers, 50 $\mathrm{mM} \mathrm{KCl}, 20 \mathrm{mM}$ Tris/HCl pH 8.4, $0.8 \mathrm{mM}$ dNTP, 0.5U Extaq DNA polymerase, 3mM MgCl2, $1 \mathrm{X}$ SYBR green (Invitrogen $^{\mathrm{TM}}$ )을 혼합하여 반응액을 제조하였고, LineGene K (BIOER, China)를 사용하여 PCR을 진행하였다. Melting curve로 $\mathrm{PCR}$ 의 유효성을 검증하였고, $\beta$-actin의 발현을 표준화하여 각 유전자의 발현을 비교하고 분석하였으 며 실험에 사용된 primer는 Table 1 과 같다.

\section{6. 세포사멸 측정}

세포사멸 정도를 확인하기 위해 Apoptosis ELISA kit (Roche Molecular Biochemicals, Germany)를 사용하였다. ELISA는 면역정량법으로 항체에 효소를 결합시켜 항원-항

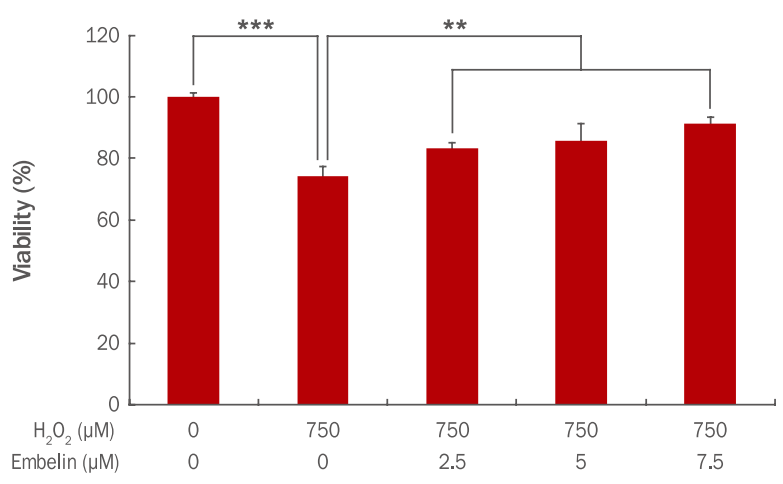

Figure 2. Cell viability on $\mathrm{H}_{2} \mathrm{O}_{2}$ in the HDFs pretreated with embelin.

HDFs were cultured in a 96-well plate for $24 \mathrm{~h}$ and additionally cells were treated with embelin for $24 \mathrm{~h}$. After $3 \mathrm{~h}$ post-treatment with embelin, $\mathrm{H}_{2} \mathrm{O}_{2}$ was applied in HDFs. After $24 \mathrm{~h}$, cell viability was measured by using WST-1 assay. The graph represents the mean \pm standard deviation of the relative cell viability in each sample from triplicate experiments $\left({ }^{* *} p<0.01,{ }^{* * *} p<0.001\right)$. HDFs, human dermal fibroblasts; WST-1, water-soluble tetrazolium salt.

체반응을 확인하는 방법이다. 세포 접종(cell seeding) 후 24 $\mathrm{h}$ 배양하고 세포에 시료와 자극처리를 한 뒤 다시 $24 \mathrm{~h}$ 동안 배양해준다. Kit에 포함된 lysis buffer $200 \mu \mathrm{L}$ 를 넣어 세포 를 용해하고 원심분리를 한다. 상층액 $20 \mu \mathrm{L}$ 를 anti-histone monoclonal antibody $80 \mu \mathrm{L}$ 와 반응시켜 1차 ELISA 반응을 유도한다(300 rpm 교반기, 상온, $2 \mathrm{~h}$ ). 반응용액을 제거하 고 incubation buffer $300 \mu \mathrm{L}$ 로 3 번씩 헹구어 준다. 이어서 2 차 anti-DNA monoclonal antibody $80 \mu \mathrm{L}$ 를 넣어 2 차 반 응을 시켜준다. 2,2'-Azino-bis (3-ethylbenzthiazoline6-sulfonic acid) (ABTS, Sigma-Aldrich) $100 \mu \mathrm{L}$ 를 첨가 하여 10-20 min 반응시킨 후 microplate reader를 사용하여 $405 \mathrm{~nm}$ 에서 반응 결과를 측정하였다.

\section{7. $\Delta \Psi \mathrm{m}$ determination}

세포사멸 지표인 미토콘드리아 막전위차(mitochondrial membrane potential, $\Delta \Psi \mathrm{m}$ )를 측정하기 위해 $\mathrm{JC}-1$ mitochondrial membrane potential detection kit (Cayman chemical, USA)를 사용하였다. 정상 세포내에서

Table 1. List of primers used in this study

\begin{tabular}{lll}
\hline Gene & Forward primer & Reverse primer \\
$\beta$-actin & GGATTCCTATGTGGGCGACGA & CGCTCGGTGAGGATCTTCATG \\
$B A X$ & CCCTTTTCTACTTTGCCAGCAA & CCCGGAGGAAGTCCAATGT \\
COX2 & CGCGGATCCGCGGTGAGAACCGTTTAC & GCGAGGAAGCGGAAGAGTCTAGAGTCGACC \\
$T N F \alpha$ & CCCAGGGACCTCTCTCTAATC & GGTTTGCTACAACATGGGCTACA \\
$I L 6$ & TAACAGTTCCTGCATGGGCGGC & AGGACAGGCACAAACACGCACC \\
\hline
\end{tabular}

$\beta$-actin, actin beta; $B A X, \mathrm{BCl}$-2-associated X protein; COX2, cyclooxygenase 2; TNF $\alpha$, tumor necrosis factor $\alpha$; IL 6 , interleukin 6 . 


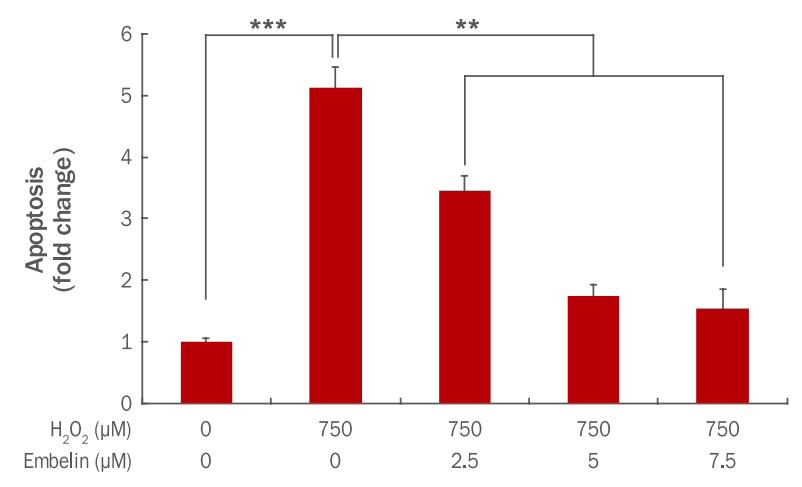

Figure 3. Inhibitory effect of apoptosis by embelin in $\mathrm{H}_{2} \mathrm{O}_{2}$ -treated HDFs.

HDFs were cultured in a $60 \mathrm{~mm}$ culture dish for $24 \mathrm{~h}$ and additionally cells were treated with embelin for $24 \mathrm{~h}$. At $3 \mathrm{~h}$ post treatment with $750 \mu \mathrm{M}$ of $\mathrm{H}_{2} \mathrm{O}_{2}$, cells were further incubated for $24 \mathrm{~h} . \mathrm{H}_{2} \mathrm{O}_{2}$-induced apoptosis was measured by Apoptosis ELISA kit. The total amount of apoptosis was decreased by embelin in a dose-dependent manner. The graph represents the mean \pm standard deviation of the apoptosis level in each sample from triplicate experiments $\left({ }^{* *} p<0.01,{ }^{* * *} p<0.001\right)$. HDFs, human dermal fibroblasts; ELISA, enzyme linked immunosorbent assay.

의 JC-1 염색시약은 미토콘드리아에 red 형광을 띠며 축적 되고, apoptosis가 일어난 세포에서는 세포질에 green 형광 을 띤다. 세포 접종 후 $24 \mathrm{~h}$ 배양하고 세포에 시료와 자극처 리를 한 뒤 $24 \mathrm{~h}$ 동안 추가 배양해준다. $\mathrm{JC}-1$ 을 첨가하여 $37^{\circ} \mathrm{C}, 20 \mathrm{~min}$ 동안 반응시킨 후, Dulbecco's PhosphateBuffered Saline (DPBS; GIBCO ${ }^{\mathrm{TM}}$, USA) buffer로 두 번 헹구어준다. Flow cytometer를 이용하여 형광값을 각 각 측정한다(Red, excitation $550 \mathrm{~nm}$, emission $600 \mathrm{~nm}$; Green, excitation $485 \mathrm{~nm}$, emission $535 \mathrm{~nm}$ ). Red/ Green fluorescence ratio를 측정하여 미토콘드리아 막전위 차로 표기하였다.

\section{8. 통계처리}

본 연구의 모든 실험들은 동일한 조건하에 독립적으로 3 회 반복 측정을 통해 수행하였으며, 실험결과는 평균 \pm 표준 편차 로 나타내었다. 실험 결과는 Student's $t$-test로 검정하였고, $p$-value 값이 $0.05,0.01,0.001$ 이하인 경우 통계적으로 유 의하다고 분석하였다 $\left({ }^{*} p<0.05,{ }^{* *} p<0.01,{ }^{* * *} p<0.001\right)$.

\section{Results and Discussion}

\author{
1. Embelin의 세포독성 및 세포보호 효과 \\ 1) Embelin의 세포독성
}

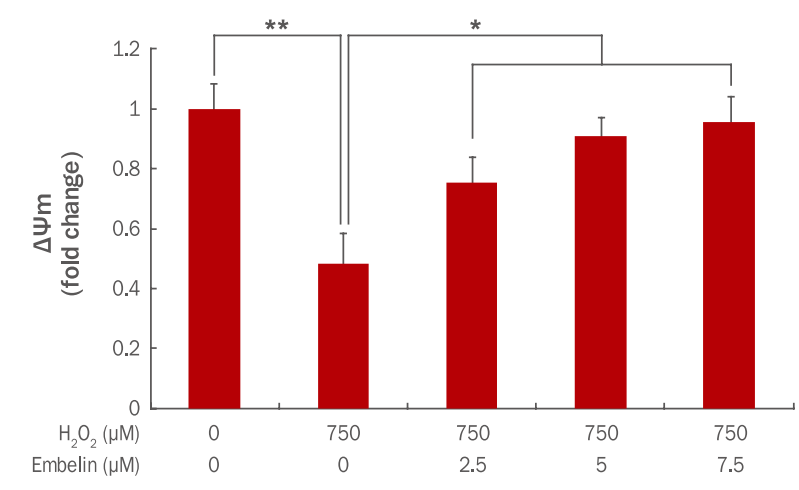

Figure 4. Restoration of $\Delta \Psi \mathrm{m}$ by embelin in $\mathrm{H}_{2} \mathrm{O}_{2}$-treated HDFs.

HDFs were cultured in a $60 \mathrm{~mm}$ culture dish for $24 \mathrm{~h}$ and additionally cells were treated with embelin for $24 \mathrm{~h}$. At $3 \mathrm{~h}$ post treatment with $750 \mu \mathrm{M}$ of $\mathrm{H}_{2} \mathrm{O}_{2}$, cells were further incubated for $24 \mathrm{~h}$. Then, $\Delta \Psi \mathrm{m}$ was measured by JC-1 mitochondrial membrane potential detection kit. The total amount of $\Delta \Psi \mathrm{m}$ was increased by embelin in a dose-dependent manner. The graph represents the mean \pm standard deviation of the $\Delta \Psi_{\mathrm{m}}$ level in each sample from triplicate experiments $\left({ }^{*} p<0.05\right.$, $\left.{ }^{* *} p<0.01\right) . \Delta \Psi \mathrm{m}$, mitochondrial membrane potential; HDFs, human dermal fibroblasts; JC-1, 5,5',6,6'-tetrachloro-1,1',3,3'tetraethylbenzimidazolylcarbocyanine iodide.

인간 진피섬유아세포에 embelin을 $2.5,5,7.5,10 \mu \mathrm{M}$ 농 도로 각각 처리하고 $24 \mathrm{~h}$ 배양 후 세포 생존율을 측정하여 embelin의 세포 독성을 확인하였다. 그 결과 embelin의 농도 에 따라 $2.5 \mu \mathrm{M}$ 에서 $97 \%, 5 \mu \mathrm{M}$ 에서 $93 \%, 7.5 \mu \mathrm{M}$ 에서 $86 \%$ 의 세포 생존율을 보였으나, $10 \mu \mathrm{M}$ 에서는 세포 생존율이 $67 \%$ 까지 떨어져 세포독성이 있는 것으로 판단되어 이후 실험에서 는 $7.5 \mu \mathrm{M}$ 을 최대 사용농도로 적용하였다(Figure 1).

\section{2) Embelin의 $\mathrm{H}_{2} \mathrm{O}_{2}$ 에 대한 세포보호 효과}

$\mathrm{H}_{2} \mathrm{O}_{2}$ 에 의한 인간 진피섬유아세포의 손상으로부터 embelin 의 보호 효과를 알아보기 위해서 embelin을 각각 2.5, 5, 7.5 $\mu \mathrm{M}$ 의 농도로 각각 $24 \mathrm{~h}$ 전처리한 다음 $\mathrm{H}_{2} \mathrm{O}_{2}$ 를 $750 \mu \mathrm{M}$ 처리 하고 $3 \mathrm{~h}$ 후 세포생존율 변화를 확인하였다. 인간 진피섬유아 세포에 embelin을 처리하지 않고 $\mathrm{H}_{2} \mathrm{O}_{2} 750 \mu \mathrm{M}$ 처리 시 $74 \%$ 로 세포생존율이 감소하였으나 embelin을 $2.5,5,7.5 \mu \mathrm{M}$ 전 처리 시 $83 \%, 86 \%, 91 \%$ 로 embelin에 의해 세포생존율이 농 도 의존적으로 유의하게 회복되는 것을 확인하였다(Figure 2).

\section{Embelin의 세포사멸 억제 효과}

\section{1) ELISA 방법을 이용한 apoptosis 측정결과}

$\mathrm{H}_{2} \mathrm{O}_{2}$ 에 의해 발생된 인간 진피섬유아세포 내 apoptosis 가 embelin에 의해 억제되는지를 확인하기 위해 Apoptosis ELISA kit를 사용하였다. 면역 특이적 반응을 이용하여 


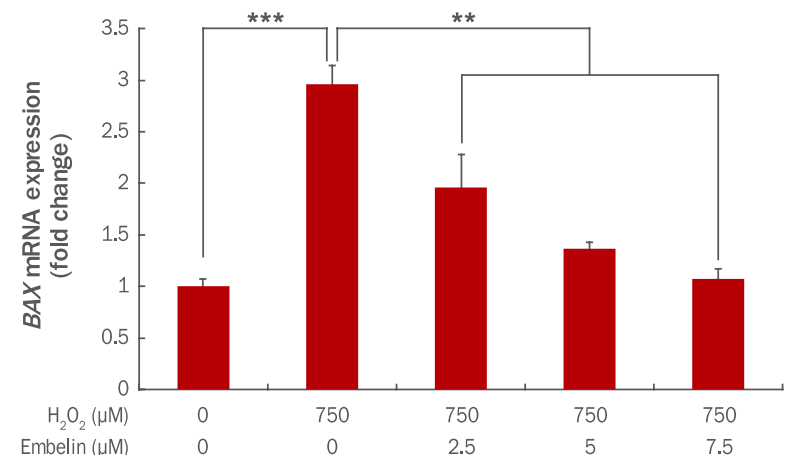

Figure 5. Inhibition of $B A X$ gene expression by embelin in $\mathrm{H}_{2} \mathrm{O}_{2}$ treated HDFs.

HDFs were pre-treated for $24 \mathrm{~h}$ after adding embelin at indicated concentrations to a culture medium. At $3 \mathrm{~h}$ after the $\mathrm{H}_{2} \mathrm{O}_{2}$ treatment, changes of $B A X$ gene expressions were examined by qRT-PCR. The $B A X$ gene expression was decreased by embelin in a dose-dependent manner. The graph represents the mean \pm standard deviation of three independent experiments $\left({ }^{* *} p<0.01,{ }^{* * *} p<0.001\right)$. HDFs, human dermal fibroblasts; $B A X$, Bcl2-associated $X$ protein; qRT-PCR, quantitative real time polymerase chain reaction.

anti-histone monoclonal antibody를 반응시켜 1차 반응을 유도하고, 이어서 anti-DNA monoclonal antibody를 이용하 여 2차 반응을 시켜주고 $\mathrm{ABTS}$ 를 첨가하여 반응을 시킨 후 405 $\mathrm{nm}$ 에서 반응 결과를 측정하였다. 그 결과 $750 \mu \mathrm{M} \mathrm{H}_{2} \mathrm{O}_{2}$ 에 의 해 apoptosis가 1에서 5.12로 증가하였으나, embelin 2.5, 5, $7.5 \mu \mathrm{M}$ 농도로 전처리 후 $750 \mu \mathrm{M} \mathrm{H}_{2} \mathrm{O}_{2}$ 를 처리 시 apoptosis 가 $3.46,1.74,1.54$ 로 감소하였다(Figure 3). 본 실험을 통해 결과적으로 embelin이 농도 의존적으로 apoptosis를 유의하 게 감소시킴으로써 세포사멸 억제에 영향을 미치는 것으로 확 인되었다.

\section{2) 미토콘드리아 막전위차 측정결과}

세포사멸 지표인 미토콘드리아 막전위차 측정은 $\mathrm{JC}-1$ mitochondrial membrane potential detection kit를 사용하 였으며, flow cytometer를 이용하여 형광값을 각각 측정하였 다. $\mathrm{JC}-1$ 염색은 미토콘드리아의 막전위 변화에 의해 정상세 포일 경우 미토콘드리아 내로 들어가 다복합체를 형성하여 빨 간색으로 나타나고, apoptosis가 일어나면 세포질에 남아 녹 색을 나타낸다(Kim et al., 2011). Red/Green fluorescence ratio를 측정하여 미토콘드리아 막전위차로 표기한 결과 $750 \mu \mathrm{M} \mathrm{H}_{2} \mathrm{O}_{2}$ 에 의해 $\Delta \Psi \mathrm{m}$ 이 1 에서 0.48 로 감소하였으나, embelin 2.5, $5,7.5 \mu \mathrm{M}$ 농도로 전처리 후 $750 \mu \mathrm{M} \mathrm{H}_{2} \mathrm{O}_{2}$ 를 처리 시 $\Delta \Psi \mathrm{m}$ 이 $0.75,0.91,0.96$ 으로 유의하게 증가하였다 (Figure 4).

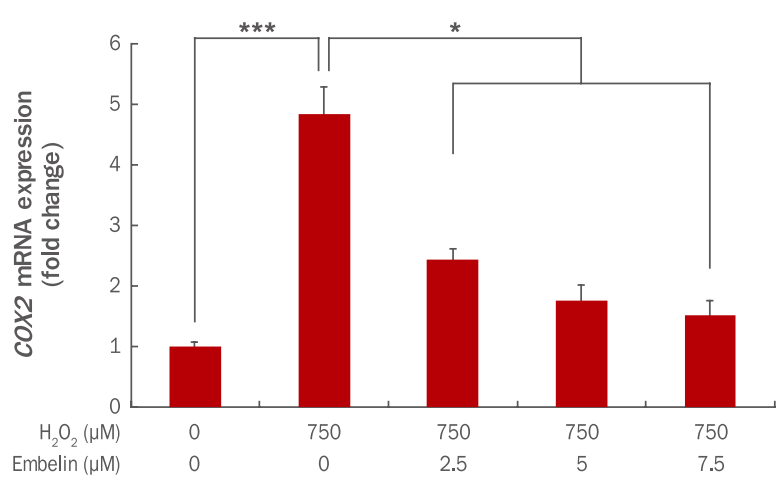

Figure 6. Inhibition of COX2 gene expression by embelin in $\mathrm{H}_{2} \mathrm{O}_{2}-$ treated HDFs.

HDFs were pre-treated for $24 \mathrm{~h}$ after adding embelin at indicated concentrations to a culture medium. At $3 \mathrm{~h}$ after the $\mathrm{H}_{2} \mathrm{O}_{2}$ treatment, changes of COX2 gene expressions were examined by qRT-PCR. The COX2 gene expression was decreased by embelin in a dosedependent manner. The graph represents the mean \pm standard deviation of three independent experiments $\left({ }^{*} p<0.05,{ }^{* * *} p<0.001\right)$. HDFs, human dermal fibroblasts; COX2, cyclooxygenase 2; qRT-PCR, quantitative real time polymerase chain reaction.

미토콘드리아는 에너지를 생성하기 위해 adenosine triphosphate (ATP)를 합성하는데 이때, 이온의 위치에너지를 이용한다. 때문에 미토콘드리아 막간공간에 양성자가 많이 분 포되어 있고 막전위가 형성된다(Reece et al., 2012). 미토콘 드리아 막투과성이 항진되면 막간공간에 존재하는 apoptosis 유도 단백질인 cytochrome $\mathrm{C}$ 가 세포질에 방출되고, 방출된 cytochrome C는 단백질 분해효소 그룹인 caspase를 단계적 으로 활성화하여 apoptosis가 실행된다(Kim et al., 2010). 본 실험을 통해 결과적으로 $\mathrm{H}_{2} \mathrm{O}_{2}$ 처리 시 $\Delta \Psi \mathrm{m}$ 이 감소하였으나 embelin이 농도 의존적으로 $\Delta \Psi \mathrm{m}$ 을 증가시킴으로써 미토콘 드리아의 기능 파괴를 막아 세포 사멸 억제에 영향을 미치는 것으로 보인다.

\section{3) $B A X$ 유전자 발현 변화}

세포사멸을 촉진하는 $B A X$ 유전자 발현에 embelin이 어 떤 영향을 나타내는지 $\mathrm{qRT}-\mathrm{PCR}$ 을 통해 확인하였다. 그 결 과 $750 \mu \mathrm{M} \mathrm{H}_{2} \mathrm{O}_{2}$ 에 의해 $B A X$ 유전자 발현이 1에서 2.96으로 증가하였으나, embelin $2.5,5,7.5 \mu \mathrm{M}$ 전처리 후 $750 \mu \mathrm{M}$ $\mathrm{H}_{2} \mathrm{O}_{2}$ 를 처리 시 $B A X$ 유전자 발현이 $1.96,1.37,1.08$ 로 유의 하게 감소하였다(Figure 5 ).

$B A X$ 는 미토콘드리아 내의 cytochrome $\mathrm{C}$ 를 세포질로 유출 시켜 세포사멸을 촉진시키는 대표적인 pro-apoptotic 유전자 이다(Han et al., 2008). 그러므로 embelin이 농도 의존적으 로 세포사멸 촉진 유전자인 $B A X$ 발현을 감소시킴으로써 세포 사멸을 억제하는 것으로 사료된다. 


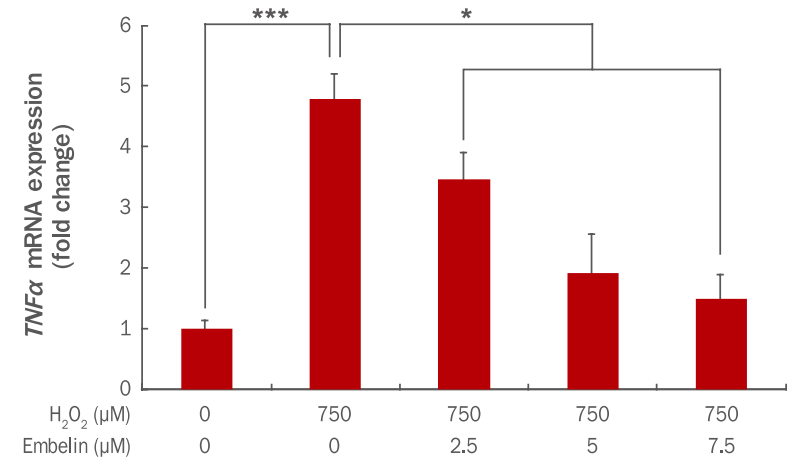

Figure 7. Inhibition of $T N F \alpha$ gene expression by embelin in $\mathrm{H}_{2} \mathrm{O}_{2}$ treated HDFs.

HDFs were pre-treated for $24 \mathrm{~h}$ after adding embelin at indicated concentrations to a culture medium. At $3 \mathrm{~h}$ after the $\mathrm{H}_{2} \mathrm{O}_{2}$ treatment, changes of $T N F \alpha$ gene expressions were examined by qRT-PCR. The $T N F \alpha$ gene expression was decreased by embelin in a dose-dependent manner. The graph represents the mean \pm standard deviation of three independent experiments $\left({ }^{*} p<0.05,{ }^{* * *} p<0.001\right)$. HDFs, human dermal fibroblasst; $T N F \alpha$, tumor necrosis factor $\alpha$; qRT-PCR, quantitative real time polymerase chain reaction.

\section{Embelin의 항염 효과}

\section{1) $C O X 2$ 유전자 발현 변화}

인간 진피섬유아세포에서 embelin에 의한 COX2 유전자 발현 변화를 $\mathrm{qRT}-\mathrm{PCR}$ 을 통해 확인하였다. 그 결과 $750 \mu \mathrm{M}$ $\mathrm{H}_{2} \mathrm{O}_{2}$ 에 의해 $\mathrm{COX} 2$ 유전자 발현이 1 에서 4.84로 증가하였으 나, embelin $2.5,5,7.5 \mu \mathrm{M}$ 전처리 후 $750 \mu \mathrm{M} \mathrm{H} \mathrm{H}_{2} \mathrm{O}_{2}$ 를 처 리 시 $C O X 2$ 유전자 발현이 $2.44,1.76,1.52$ 로 감소하였다 (Figure 6).

COX는 arachidonic acid로부터 prostaglandin을 생산하 는 과정에서 작용하는 효소이며 COX1, COX2가 존재한다. 그 중 $\mathrm{COX} 2$ 는 염증을 포함한 다양한 자극인자에 의해 단기 간 내에 급격히 발현되는 것으로 알려져 있다(Vane et al., 1998). 그러므로 embelin이 농도 의존적으로 염증유발 유전 자인 COX2 발현을 감소시킴에 따라 염증매개 물질의 생성을 줄여 인간 진피섬유아세포 내 염증 발생 또한 감소될 것으로 판단된다.

\section{2) $T N F \alpha$ 유전자 발현 변화}

인간 진피섬유아세포에서 embelin에 의한 $T N F \alpha$ 유전자 발현변화를 $\mathrm{qRT}-\mathrm{PCR}$ 을 통해 확인하였다. 그 결과 $750 \mu \mathrm{M}$ $\mathrm{H}_{2} \mathrm{O}_{2}$ 에 의해 $T N F \alpha$ 유전자 발현이 1 에서 4.79 로 증가하였으 나, embelin $2.5,5,7.5 \mu \mathrm{M}$ 전처리 후 $750 \mu \mathrm{M} \mathrm{H}_{2} \mathrm{O}_{2}$ 를 처 리 시 $T N F \alpha$ 유전자 발현이 $3.46,1.92,1.50$ 으로 감소하였다 (Figure 7).

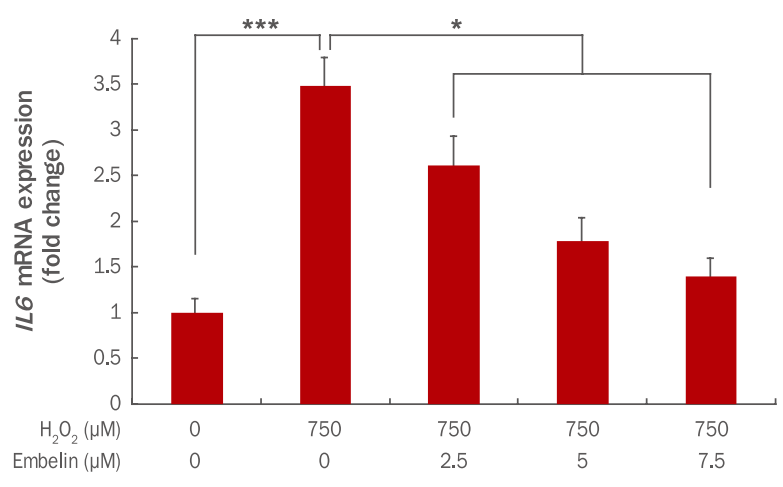

Figure 8. Inhibition of IL6 gene expression by embelin $\mathrm{H}_{2} \mathrm{O}_{2}-$ treated HDFs.

HDFs were pre-treated for $24 \mathrm{~h}$ after adding embelin at indicated concentrations to a culture medium. At $3 \mathrm{~h}$ after the $\mathrm{H}_{2} \mathrm{O}_{2}$ treatment, changes of $I L 6$ gene expressions were examined by qRTPCR. The IL6 gene expression was decreased by embelin in a dosedependent manner. The graph represents the mean \pm standard deviation of three independent experiments $\left({ }^{*} p<0.05,{ }^{* * *} p<0.001\right)$. HDF, human dermal fibroblast; IL6, interleukin 6; qRT-PCR, quantitative real time polymerase chain reaction.

IL1 $\beta$ 과 함께 염증반응 초기에 작용하는 cytokine인 TNF $\alpha$ 는 스트레스 상태에서 염증반응의 결정적인 매개체 역할 을 한다(Ventura et al., 2003). 또한 급성 염증반응에서 중 요한 역할을 하는 염증성 질환의 주요 조절인자이자 종양 발 생 시에 세포괴사(necrosis)를 유도하여 종양 발생의 감시 기 전으로 사용되기도 한다(Aqarwal et al., 1988). 그러므로 embelin이 농도 의존적으로 급성 염증반응의 주요 조절인자 인 TNFa 발현을 감소시킴으로써 인간 진피섬유아세포 내 급 성 염증반응 또한 억제될 것으로 판단된다.

\section{3) $/ L 6$ 유전자 발현 변화}

인간 진피섬유아세포에서 embelin에 의한 IL6 유전자의 발현변화를 $\mathrm{qRT}-\mathrm{PCR}$ 을 통해 확인하였다. 그 결과 $750 \mu \mathrm{M}$ $\mathrm{H}_{2} \mathrm{O}_{2}$ 에 의해 $I L 6$ 유전자 발현이 1 에서 3.48 로 증가하였으나, embelin $2.5,5,7.5 \mu \mathrm{M}$ 전처리 후 $750 \mu \mathrm{M} \mathrm{H}_{2} \mathrm{O}_{2}$ 를 처리 시 IL6 유전자 발현이 $2.61,1.78,1.39$ 로 감소하였다(Figure $8)$.

IL6는 다양한 기능을 하는 cytokine으로 염증반응과 면역 반응을 매개하는 것으로 잘 알려져 있다(Pang et al., 1994; Zhai et al., 2001). 또한 염증 시 과잉 생산되어 염증 정도를 나타내는 지표로도 이용된다(Hirano et al., 1986; Frydas et al., 1996). 그러므로 embelin이 농도 의존적으로 염증 지 표로 이용되는 IL6 발현을 감소시킴으로써 인간 진피섬유아 세포 내 염증반응 또한 억제될 것으로 판단된다. 


\section{Conclusion}

전 세계적으로 항노화 화장품에 대한 소재 개발 연구가 증 가하고 있으며, embelin에 대한 의 - 약학 분야에서의 항암, 항염 및 항산화 선행연구가 보고되었으나 embelin의 화장품 원료 활용으로의 연구는 전무한 편이다. 따라서 본 연구에서 는 embelin의 항노화 화장품 원료로서의 가능성을 확인하기 위하여 인간 진피섬유아세포에 embelin을 농도별 전처리 후 $\mathrm{H}_{2} \mathrm{O}_{2}$ 로 산화적 스트레스를 유도한 다음 이로 인해 나타나는 세포의 변화를 통해 embelin의 세포사멸 억제, 항염 효과를 확인하였다.

첫째, 인간 진피섬유아세포에서 embelin의 세포독성 및 $\mathrm{H}_{2} \mathrm{O}_{2}$ 에 대한 세포보호 효과를 알아보았다. 그 결과 embelin 을 $2.5,5,7.5 \mu \mathrm{M}$ 농도로 각각 처리 시 $97 \%, 93 \%, 86 \%$ 의 생존율을 보였으나, $10 \mu \mathrm{M}$ 농도에서 세포 생존율이 $67 \%$ 까지 떨어져 세포독성이 있는 것으로 판단되었다. 이후 실험에서는 $7.5 \mu \mathrm{M}$ 을 최대 사용농도로 적용하였다. 또한 인간 진피섬유 아세포에 embelin을 각각 $2.5,5,7.5 \mu \mathrm{M}$ 의 농도로 전처리 후 $\mathrm{H}_{2} \mathrm{O}_{2}$ 를 $750 \mu \mathrm{M}$ 처리한 경우 세포 생존율이 농도 의존적 으로 회복되는 것을 확인하였다.

둘째, 인간 진피섬유아세포에서 embelin의 세포사멸 억제 효과를 확인하였다. $\mathrm{H}_{2} \mathrm{O}_{2}$ 에 의해 발생된 인간 진피섬유아세 포 내 세포사멸이 embelin에 의해 억제되는지를 확인한 결 과, embelin이 농도 의존적으로 세포사멸을 감소시키고, 세 포사멸 지표인 미토콘드리아 막전위차를 증가시켰다. 또한 embelin은 세포사멸을 촉진하는 대표 유전자인 $B A X$ 의 발현 량을 감소시켜 미토콘드리아로부터 세포질로 cytochrome C 가 방출되는 것을 억제함으로써 세포사멸 억제효과가 있음을 확인하였다.

셋째, 인간 진피섬유아세포에서 embelin의 항염 효과를 확 인하였다. Embelin의 농도가 증가할수록 대표적인 염증반응 전사인자인 NF- $\mathrm{\kappa B}$ 하위 유전자인 $C O X 2, T N F \alpha, I L 6$ 의 염 증 유발 유전자 발현이 감소하는 것을 확인하였다.

본 연구결과를 통해 embelin은 농도 의존적으로 $\mathrm{H}_{2} \mathrm{O}_{2}$ 에 의해 손상된 인간 진피섬유아세포의 세포생존율을 회복시키 고, 세포사멸 억제 및 항염 효과가 있음을 확인하였다. 그러 므로 embelin은 인간 진피섬유아세포의 항노화 효능을 가진 화장품 소재로서 활용가능 하리라고 판단된다. 다만 이번 연 구결과를 검증하기 위한 임상실험에서의 추가 연구가 필요하 다고 사료된다.

This work is part of the Hee-Jung Yong's Ph.D. thesis at the Konkuk University, Seoul, Korea.

\section{Acknowledgements}

이 논문은 해양수산부의 재원으로 해양생명공학기술개발사 업(과제번호: 20150184) 연구개발비 지원에 의해 수행되었습 니다.

\section{References}

Aqarwal S, Drysdale BE, Shin HS. Tumor necrosis factormediated cytotoxicity involved ADP-ribosylation. Journal of Immunology, 140: 4187-4192, 1988.

Baeuerle PA. Pro-inflammatory signaling: last pieces in the NF-kappaB puzzle? Current Biology, 8: R19-22, 1988.

Baeuerle PA, Henkel T. Function and activation of NFkappa B in the immune system. Annual Review of Immunology, 12: 141-179, 1994.

Dhadde SB, Nagakannan P, Roopesh M, Anand Kumar SR, Thippeswamy BS, Veerapur VP, Badami S. Effect of embelin against 3-nitropropionic acidinduced Huntington's disease in rats. Biomedicine \& Pharmacotherapy, 77: 52-58, 2016.

Dharmapatni AA, Cantley MD, Marino V, Perilli E, Crotti TN, Smith MD, Haynes DR. The X-linked inhibitor of apoptosis protein inhibitor embelin suppresses inflammation and bone erosion in collagen antibody induced arthritis mice. Mediators of Inflammation, 2015: ID 564042, 2015.

Frydas S, Karaqouni E, Dotsika E, Reale M, Barbacane RC, Vlemmas I, Anoqianakis G, Trakatellis A, Conti P. Generation of TNF alpha, IFN gamma, IL-6, IL-4 and IL10 in mouse serum from trichinellosis: effect of the anti-inflammatory compound 4-deoxypyridoxine (4DPD). Immunology Letters, 49: 179-184, 1996.

Gomez-Nicola D, Valle-Argos B, Nieto-Sampedro M. Blockade of IL-15 activity inhibits microglial activation through the NFkappaB, p38, and ERK1/2 pathways, reducing cytokine and chemokine release. Glia, 58: 264-276, 2010.

Han SI, Kim YS, Kim TH. Role of apoptotic and necrotic cell death under physiologic conditions. BMB Reports, 41: 1-10, 2008.

Hirano T, Yasukawa K, Harada H, Taga T, Watanabe Y, Matsuda T, Kashiwamura S, Nakajima K, Koyama K, Iwamatsu A, et al. Complementary DNA for a novel 
human interleukin (BSF-2) that induces B lymphocytes to produce immunoglobulin. Nature, 324: 73-76, 1986.

Kang ES, Iwata K, Ikami K, Ham SA, Kim HJ, Chang KC, Lee $\mathrm{JH}$, Kim JH, Park SB, Kim JH, et al. Aldose reductase in keratinocytes attenuates cellular apoptosis and senescence induced by UV radiation. Free Radical Biology and Medicine, 50: 680-688, 2012.

Kim HY, Kim BR, Kim GD, Kim HJ. The effect of cisplatin on endoplasmic reticulum stress of human cervical cancer cell. Korean Journal of Obstetrics and Gynecology, 54: 175-183, 2011.

Kim HJ, Lee JM, Moon SH, Park HR. Protective effect of Prunella spica extracts against $\mathrm{H}_{2} \mathrm{O}_{2}$-induced cytotoxicity in PC12 cells. Journal of Life Science, 20: 1121-1126, 2010.

Lee NK, Ku JE, Han HS. Cytoprotective and antiinflammatory effects of 6-shogaol on human dermal fibroblasts. Asian Journal of Beauty and Cosmetology, 15: 367-376, 2017.

Lee S, Han HS, An IS, Ahn KJ. Effects of amentoflavone on anti-inflammation and cytoprotection. Asian Journal of Beauty and Cosmetology, 14: 201-211, 2016.

Li Y, Li D, Yuan S, Wang Z, Tang F, Nie R, Weng J, Ma L, Tang B. Embelin-induced MCF-7 breast cancer cell apoptosis and blockade of MCF-7 cells in the G2/M phase via the mitochondrial pathway. Oncology Letters, 5: 10051009, 2013.

Longley BJ, Braverman IM, Edelson RL. Immunology and the skin. current concepts. Annals of the New York Academy of Sciences, 548: 225-232, 1988.

Mazière C, Conte MA, Degonville J, Ali D, Mazière JC. Cellular enrichment with polyunsaturated fatty acids induces an oxidative stress and activates the transcription factors AP1 and NFkappaB. Biochemical and Biophysical Research Communications, 265: 116-122, 1999.

Mori T, Doi R, Kida A, Nagai K, Kami K, Ito D, Toyoda E, Kawaguchi Y, Uemoto S. Effect of the XIAP inhibitor embelin on TRAIL-induced apoptosis of pancreatic cancer cells. The Journal of Surgical Research, 142: 281-286, 2007.
Naik SR, Niture NT, Ansari AA, Shah PD. Anti-diabetic activity of embelin: involvement of cellular inflammatory mediators, oxidative stress and other biomarkers. Phytomedicine, 20: 797-804, 2013.

Nomoto Y, Yamamoto M, Fukushima T, Kimura H, Ohshima $\mathrm{K}$, Tomonaga M. Expression of nuclear factor kappaB and tumor necrosis factor alpha in the mouse brain after experimental thermal ablation injury. Neurosurgery, 48: 158-166, 2001.

Pang G, Couch L, Batey R, Clancy R, Cripps A. GM-CSF, IL-1 alpha, IL-1 beta, IL-6, IL-8, IL-10, ICAM-1 and VCAM-1 gene expression and cytokine production in human duodenal fibroblasts stimulated with lipopolysaccharide, IL-1 alpha and TNF-alpha. Clinical \& Experimental Immunology, 96: 437-443, 1994.

Radhakrishana N, Gnanamani A. 2, 5-dihydroxy-3undecyl-1, 4-benzoquinone (embelin)-a second solid gold of India: a review. International Journal Pharmacy \& Pharmaceutical Sciences, 6: 23-30, 2014.

Reece JB, Urry LA, Cain ML, Wasserman SA, Minorsky PV, Jackson RB. Campbell Biology. Pearson, San Francisco, p163, 2012.

Singh D, Singh R, Singh P, Gupta RS. Effects of embelin on lipid peroxidation and free radical scavenging activity against liver damage in rats. Basic \& Clinical Pharmacology \& Toxicology, 105: 243-248, 2009.

Vane JR, Bakhle YS, Botting RM. Cyclooxygenase 1 and 2. Annual Review of Pharmacology and Toxicology, 38: $97-$ 120, 1998.

Ventura JJ, Kennedy NJ, Lamb JA, Flavell RA, Davis RJ. c-Jun $\mathrm{NH}(2)$-terminal kinase is essential for the regulation of AP-1 by tumor necrosis factor. Molecular and Cellular Biology, 23: 2871-2882, 2003.

Wajant H, Pfizenmaier K, Scheurich P. Tumor necrosis factor signaling. Cell Death \& Differentiation, 10: 45-65, 2003.

Zhai R, Liu G, Yang C, Huang C, Wu C, Christiani DC. The G to C polymorphism at -174 of the interleukin- 6 gene is rare in a Southern Chinese population. Pharmacogenetics, 11: 699-701, 2001. 


\title{
국문초록
}

\section{Embelin의 세포사멸 억제 및 항염 효능}

\author{
용희정 ${ }^{1,2}$, 김규리 ${ }^{2}$, 안진정 ${ }^{3}$, 안인숙 ${ }^{4}$, 김영삼 ${ }^{5^{*}}$ \\ ${ }^{1}$ 아름다운사람들 뷰티스쿨 강사부, 경기도 성남시, 한국 \\ ${ }^{2}$ 건국대학교 생물공학과, 서울, 한국 \\ ${ }^{3}$ 수원여자대학교 뷰티아트과, 경기도 수원시, 한국 \\ ${ }^{4}($ 주)진셀팜, 서울, 한국 \\ ${ }^{5}$ 건국대학교 산업대학원 이미지산업학과, 서울, 한국
}

목적: Embelin은 인도의 중요한 전통 약용 식물인 Embelia ribes Burm. (Myrsinaceae)의 주요 활성 성분으로 항암, 항염증 및 항 산화 효과에 관련된 의약학 연구가 진행되었으나 화장품 원료 활용으로서의 연구는 전무한 실정이다. 그러므로 본 연구에서는 embelin의 세포사멸 억제, 항염 효능를 검증하여 화장품 소재로서의 가능성을 확인하고자 하였다. 방법: 세포 생존율은 water soluble tetrazolium salt (WST-1) assay의 원리를 이용하여 측정하였다. Embelin에 의한 인간 진피섬유아세포 내에서 일어나는 세 포사멸억제 효과와 항염 효과의 유전자 발현패턴을 정량적으로 분석하기 위하여 quantitative real time polymerase chain reaction (qRT-PCR)을 실행하였다. 세포사멸 정도를 확인하기 위해 Apoptosis ELISA kit를 사용하였고, 세포사멸 지표인 미토콘드리아 막전위차를 측정하기 위해 5,5', 6,6'-tetrachloro-1,1', 3,3'-tetraethylbenzimidazolylcarbocyanine iodide (JC-1) mitochondrial membrane potential detection kit를 사용하였다. 결과: WST-1 분석을 통해 과산화수소 $\left(\mathrm{H}_{2} \mathrm{O}_{2}\right)$ 에 의한 감소된 세포 생존율이 embelin에 의해 농도 의존적으로 회복되는 것을 확인하였다. $\mathrm{H}_{2} \mathrm{O}_{2}$ 로 유도된 세포사멸이 embelin에 의해 회복되었고, 농도 의존적 으로 세포 사멸을 촉진하는 $B A X$ 유전자 발현은 감소하였으며 미토콘드리아 막전위차는 증가하였다. 이를 통해 embelin이 $\mathrm{H}_{2} \mathrm{O}_{2}$ 처 리된 인간 진피섬유아세포에서 세포사멸 억제 기능을 한다는 것을 확인하였다. $\mathrm{H}_{2} \mathrm{O}_{2}$ 처리된 인간 진피섬유아세포에서 embelin의 항염증 효과를 알아보기 위해 염증을 유발하는 cyclooxygenase 2 (COX2), tumor necrosis factor $\alpha$ (TNF $\alpha$ ), interleukin 6 (IL6)의 유전자 발현을 분석한 결과, embelin에 의해 농도 의존적으로 유의하게 감소하는 것을 확인하였다. 결론: Embelin이 세포사멸 억 제 효능 및 항염 효능을 가진 항노화 화장품 성분으로서 활용 가능성이 있다고 판단된다.

핵심어: Embelin, 항산화, 항염증, 항노화, 인간 진피섬유아세포

이 논문은 해양수산부의 재원으로 해양생명공학기술개발사업(과제번호: 20150184) 연구개발비 지원에 의해 수행되었습니다.

\section{참고문헌}

이나경, 구정은, 한효선. 인간진피섬유아세포에서 6-shogaol의 세포보호 및 항염증 효과. 아시안뷰티화장품학술지, 15 : 367-376, 2017.

이송정, 한효선, 안인숙, 안규중. Amentoflavone의 항염증 및 세포 보호 효과. 아시안뷰티화장품학술지, 14: 201-211, 2016 . 


\title{
中文摘要
}

\section{Embelin的细胞凋亡抑制以及抗炎作用}

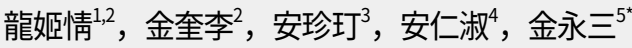 \\ 美丽人美容学校讲师部，京畿道城南市，韩国 \\ 2建国大学生物工学科, 首尔, 韩国 \\ 水原女子大学美容艺术科，京畿道水原市，韩国 \\ ${ }^{4}($ 株)健熙普，首尔，韩国 \\ 建国大学产业大学院影像产业学科, 首尔, 韩国
}

目的: Embelin是一种印度的重要传统药用植物Embelia ribes Burm. (Myrsinaceae)的主要活性成分, 据医学研究报道具 有抗癌、抗炎症以及抗氧化作用，但作为化妆品原料的应用研究至今没有。因此通过调查embelin的细胞凋亡抑制以及 抗炎作用，探索作为化妆品原料的应用可行性。方法: 利用water soluble tetrazolium salt (WST-1) assay原理测定细胞生 存率; 为了定量分析人真皮成纤维细胞内细胞凋亡抑制效果和抗炎效果的遗传因子的表达, 利用quantitative real time polymerase chain reaction (qRT-PCR)来测定。利用Apoptosis ELISA kit确认细胞凋亡程度, 为测定细胞凋亡标志, 即, 线粒体膜电位差利用5,5', 6,6'-tetrachloro-1,1', 3,3'-tetraethylbenzimidazolylcarbocyanine iodide (JC-1) mitochondrial membrane potential detection kit来测定。结果: 通过WST-1确认因 $\mathrm{H}_{2} \mathrm{O}_{2}$ 减少的细胞生存率由embelin根据浓度依赖性逐 渐恢复; 因 $\mathrm{H}_{2} \mathrm{O}_{2}$ 诱导细胞凋亡的细胞生存率由embelin根据浓度依赖性逐渐恢复, 促进细胞凋亡的BAX遗传因子的表达 减少，线粒体膜电位差反而增加。通过以上研究确认embelin抑制 $\mathrm{H}_{2} \mathrm{O}_{2}$ 处理的人真皮成纤维细胞的细胞凋亡。在 $\mathrm{H}_{2} \mathrm{O}_{2}$ 处 理的人真皮成纤维细胞中, 确认embelin的抗炎症效果, 分析炎症诱发因子cyclooxygenase 2 (COX2)、tumor necrosis factor ( TNF $\alpha$ )、 interleukin 6 (IL6)等遗传因子表达, 其结果发现利用embelin处理后, 以上遗传因子根据浓度依赖性减 少。结论: Embelin抑制细胞凋亡, 具有抗炎作用, 因此作为抗衰老化妆品原料充分具有可行性。

关键词: Embelin，抗氧化，抗炎症，抗衰老，人真皮成纤维细胞 